\title{
A New Approach to the Ordered Classification of Critical Factors in the Degradation Processes of River Basins
}

\author{
Antonio Cunha Nunes, Fernando B. Mainier, Robson Rosa Branco and Carlos Alberto Pereira Soares \\ Escola de Engenharia, Universidade Federal Fluminense, Niterói, Rio de Janeiro, Brazil
}

\begin{abstract}
The aim of this paper is to present through information collected via qualitative analysis in order to provide an alternative perspective to classify critical factors and their correlations in the processes of degradation of river basins in countries in development in an ordered way. This study was started with a bibliographical review for gathering relevant information about the main factors, which was submitted to specialists and related professionals via survey developed in a format of answers on Likert scale, with the analyses of data from the respondents as well as their contribution within sample assembly exploratory factorial analysis and the charge factor item from the questionnaire with usage of polychoric correlation matrix with which it is proposed to establish the ordering of the factors relevance as well as their correlations through parametric statistical analysis with the usage of a generalized model of partial credit which belongs to the family of the models for polyatomic gradual answers to the item response theory (IRT) and the applying of cluster analysis (ICLUST) with the usage of both alpha and omega coefficient for the estimation of the variables group, with the $\mathrm{R}$ tool. As a result, the present study aims to establish a comprehension of the main factors for the ordering of the actions and attention of public and private sectors towards the preservation of urban river basins.
\end{abstract}

Key words: Degradation, river basins, critical factors, society an environment, psychometry.

\section{Introduction}

The management of water resources based on the territorial clipping of water basins, especially the urban ones, became more evident in the beginning of the 1990's when the principles of Dublin were accorded in a preparatory meeting for the Rio-92 summit. The Principle establishes that the management of water, to be efficient, must be integrated and take into consideration all aspects: physical, social and economic ones.

According to Porto, et al. [1] the main problem which must be controlled by management is the integration of various aspects which interfere in the use of water resources and its environmental protection. Water basins allow this integrated approach and, say Yassuda [2] "the basin is a unique phase of interaction of the water with the physical means, the biotic ones and the social, economic and

Corresponding author: Fernando B. Mainier, professor, E-mail: fmainier@uol.com.br cultural environment”.

The studies of water basins essentially urbanized has trigged more and more the interest of researchers, mainly towards environmental preservation and the maintenance of essential resources which may contribute for the social-economic sustainability of several populations that live alongside such locations, which due to its continuous occupation, establish pressures, be it on the social-economic area or in the environmental one, causing an impact in the quality of life of the human being and its environment [3].

The essentially urban water basins, especially those which go through great metropolis in countries in development, suffer the consequences of unplanned urbanization, the negligence of public authorities, and many times, lack of consciousness and environmental education of local populations. In order to better understand the Evolution of the environmental deterioration of a certain ecosystem it is necessary to know the main problems related to this environment, so that it is possible to feed with relevant information 
the direction of preservation actions, and if necessary, mitigating ones.

Deterioration factors raised from bibliographical reviews are used to feed the basis of knowledge, generating important information in order to define critical factors of environmental deterioration and so, understand the dynamics of the changes in such environment. The definition of these critical factors of environmental quality can be faced with data raised from field search and evaluate the quality of this information, since this primary data correspond to the reality of the studied environment [4].

As main generating factors of deterioration of water basins, some of them are often linked to illegal sewage connections and the process of river siltation; besides the disposal of urban waste, sanitary and industrial effluents are considered as the most impacting ones, according to the results shown in Table 1.

The present study proposes the application of methodologies capable of identifying basic sources of environmental deterioration of urbanized water basins, highlighting its main actors and verifying the level of criticality in the processes of deterioration and of the several considered factors.

The main questions in the research were: "Doing a qualitative analysis to offer an alternative perspective to orderly classify critical factors in the processes of deterioration of urban water basins", and establish a comprehension of the main factors for the ordering of actions and attention of public and private sectors towards the factors of preservation of urban river basins. In order to answer these questions, the approach involved three stages: bibliographical research, collection of opinions from specialists and data analysis.

\section{Material and Methods}

This research was based on the Imboaçu River Basin, fully inserted in the city of São Gonçalo, Rio de Janeiro, Brazil, with a drainage area of $14 \mathrm{~km}^{2}$. The $10 \mathrm{~km}$ river flows through the urban perimeter, densely populated with about one hundred thousand inhabitants and characterized by a serious urban disorganization. Anthropic actions are observed when the river crosses an area of gravel exploration, with its banks grounding and intense circulation of heavy vehicles. The deficiency of solid waste collection and the discharge of fresh sewage are easily observed on the river banks and gutters, contributing to its intense degradation. The river channeling processes and adaptations to the urban environment are presented in Figs. 1 and 2.

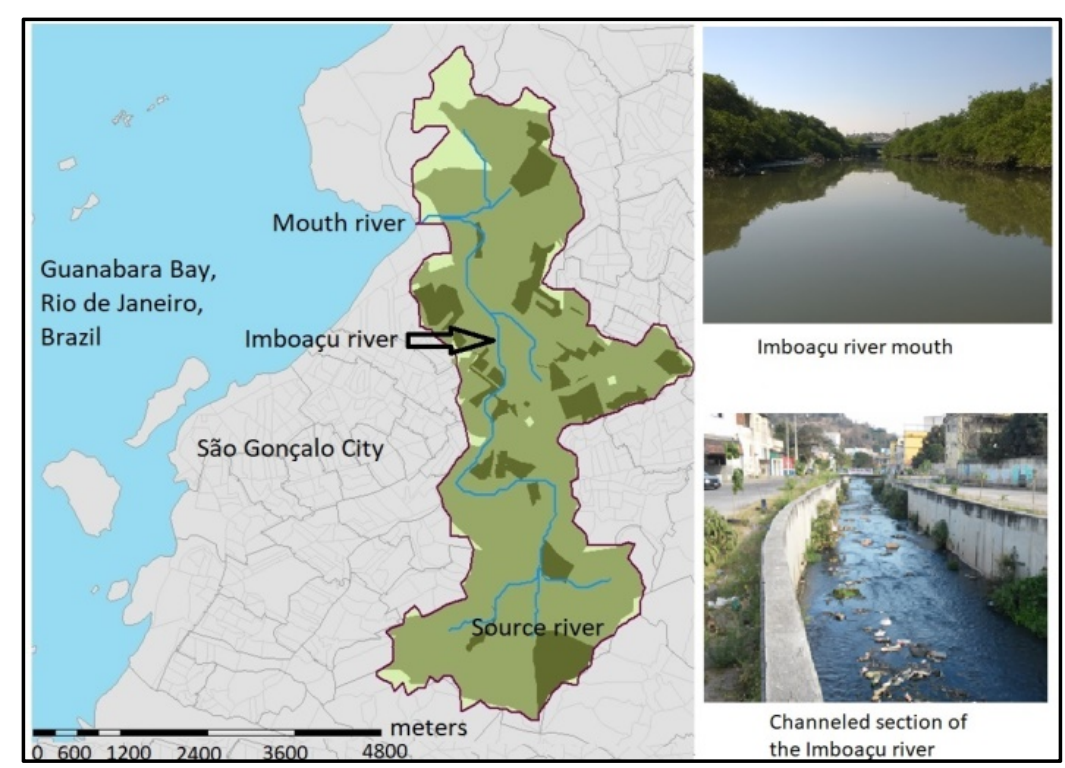

Fig. 1 Location map of the Imboaçu River Basin and aspects of the mouth of the river that flows into Guanabara Bay (Rio de Janeiro, Brazil) and part of the channeled river that runs through the city of S. Gonçalo. 


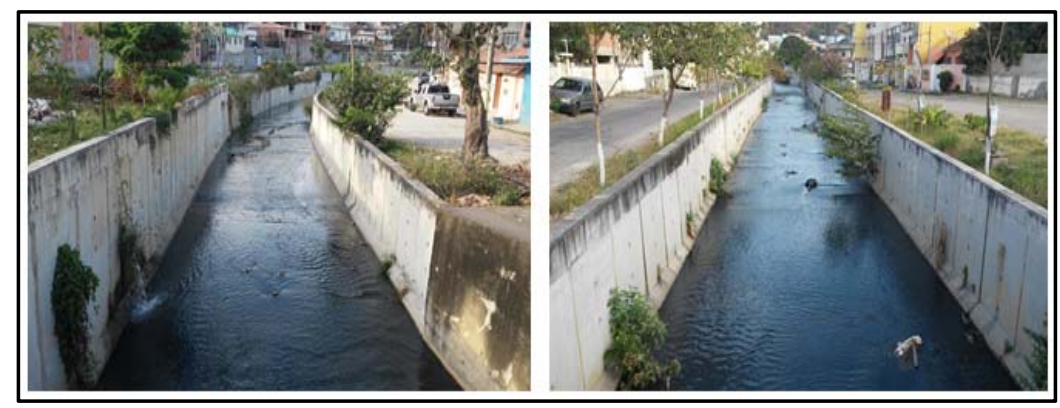

Fig. 2 Channeled section of Imboaçu River.

The factors raised were submitted by a survey tool to approximately four hundred specialists and professionals, at which it was used the Likert scale in order to establish the relevances of the factors, according to the answers from the 282 respondents. The data obtained by the survey were treated and analyzed with the $\mathrm{R}$ tool and packages of statistical and parametric analysis in the intention of evaluating the reliability of the sample and the ordering of the factors and their correlations, with the objective of achieving a better comprehension about their relevancies and related interactions.

\subsection{Factors of Deterioration of Urban Water Basins}

The collection of data raised by bibliographical had the objective building the theoretical fundamentation indispensable for the discussion and analysis of the several processes and phenomena inherent to the object of study. In the analysis process of such data there were 22 critical factors for the deterioration of basins severely anthropized. Initially, starting from the common sense, it is considered that, almost exclusively, only sewage and thrash are the most essentially deteriorating factors. However, a more profound study points a series of factors that interact in an important way with the deterioration of urbanized water basins.

All critical factors were conceptually treated, observing the terms, similar expressions and peculiarities from each of the authors that exposed them. Such procedure had the objective of avoiding that terms with differences only in the semantic field were considered distinct factors, as per described by Branco [4]. Being so, it was observed, judiciously, that each factor with the intention of avoiding repetitions, being therefore, reduced to 18 [4].

Table 1 below presents the degradation factors based on the following references [5-19].

The measuring tool used on the survey was the Likert scale. The present paper used the five-point-classic-scale as per proved by Wakita, et al. [20] and inserted in a Likert scale as "Very Little Relevant”; "Little Relevant”; "Relevant”; "Very Relevant”; "Extremely Relevant”.

The means used to do the survey was the utilization of an online form on Google Forms platform. The online form was chosen due to its readiness to send the survey to the e-mail boxes of possible respondents, and on academic networks and professionals interested on the topic.

Table 1 Bibliographic review of degradation factors.

\begin{tabular}{|l|}
\hline Illegal sewage connection \\
\hline River siltation process \\
\hline Street washing \\
\hline Dumping of industrial effluents \\
\hline Agrotoxics sliding \\
\hline Waterproofing of soil and surfaces \\
\hline Dumping of urban sanitary effluents \\
\hline Solid material sliding \\
\hline Riverbed rectification \\
\hline Irregular dumping of urban waste \\
\hline Irregular occupation \\
\hline Global climate change \\
\hline Drainage of flooded areas \\
\hline Urban waste sliding \\
\hline Underground manure drainage \\
\hline Introduction of exotic species \\
\hline Riparian deforestation \\
\hline Rain sewage \\
\hline
\end{tabular}


Besides, with that platform it was possible to distribute the critical factors in a random way for each respondent, which was a positive factor in the present type of research in order to avoid that the order of the critical factor on the survey could influence the respondents. The survey was sent in the period between 06/04/2016 and 20/04/2016, obtaining a total of 282 respondents (Fig. 3).

In the beginning of the survey, the respondent is invited to qualify his/her professional profile. The fields to be filled by the respondents were related to their Jobs, position and time of experience as shown in Fig. 4.

\section{Results and Discussions}

\subsection{Data Processing Considerations}

In the first phase of the data processing, there were made analysis of the correlation of each respondent and his/her contribution within the group of the sample through exploratory factorial analysis (EFA). Commonly, researchers consider a charge of absolute value higher than 0.3 as being important. However, the significance of a charge of the factor will depend on the size of the sample. Pituch and Stevens [21] made a table of critical values with which the charges can be compared. In resume, he recomends that for a sample size 50, a charge of 0.722 may be considered significant. For a size 100, the charge must be higher than 0.512 .

For a 200, it must be higher than 0.364 . For a 300 it must be higher than 0.298 . For a 600 , it must be higher than 0.21 and for a 1,000 , it must be higher than 0.162. Having as basis the Pituch and Stevens [21] table, there were identified the respondents that charge less $(0.3)$ on their respective factor and thus, from the

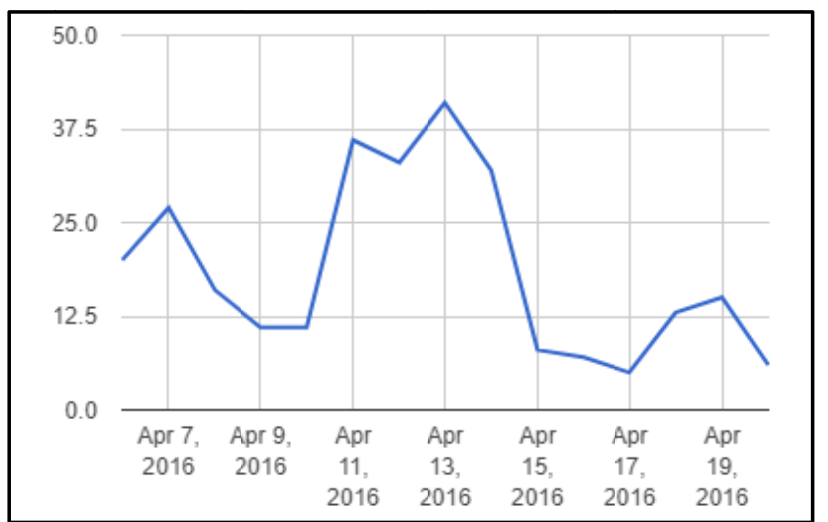

Fig. 3 Temporal window of the survey's answers and its respective flux of answers.

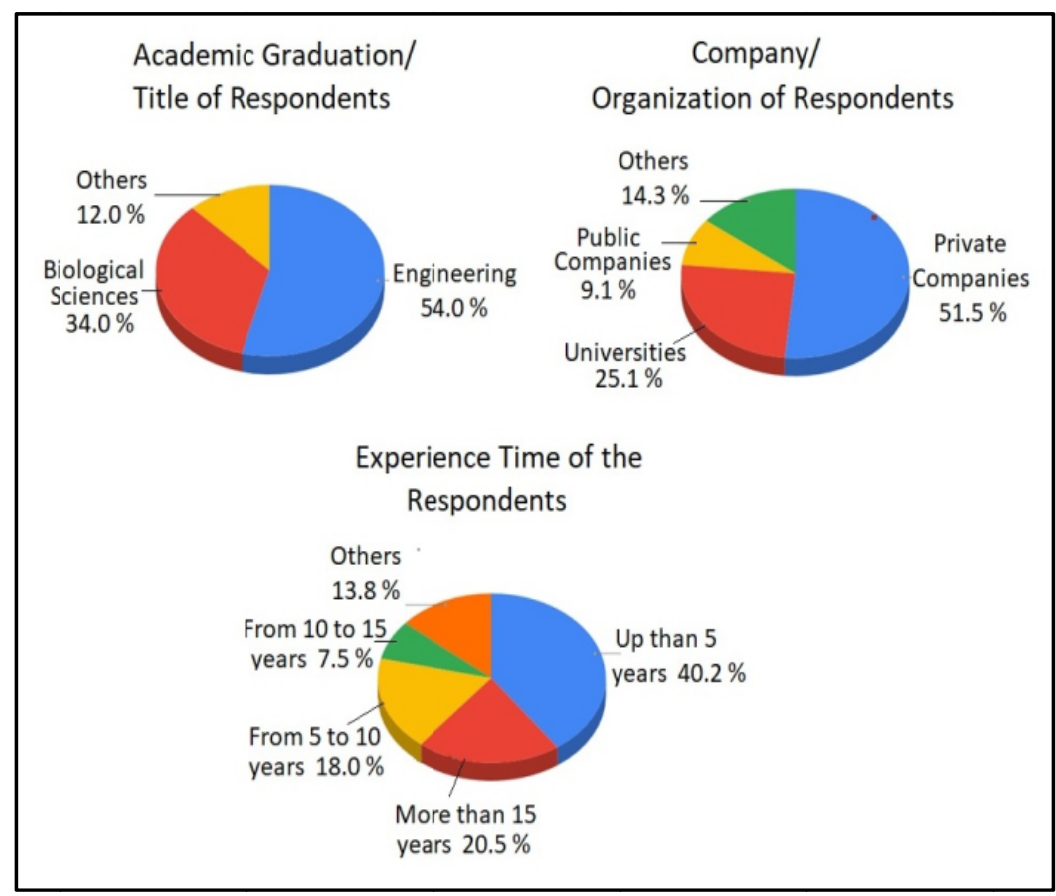

Fig. 4 Professional qualification of the respondents. 
total of 282 respondents, 74 of them had the factor of charge less than 0.3 and were excluded from the research, staying an even more significant amount of respondents, 208.

Even with the exclusion of the 74 with charge inferior to 0.3 , it still is kept a proportion of 11 respondents by item (variable), which stays within a number between 10 and 15 participants by variable. Nunnally [22], recommends having ten times more participants than variables. Kass and Tinsley [23] recommend having between 5 and 10 participants per variable up to a total of 300 .

On the second phase of the data processing, there was developed the factorial analysis of the (variable) items Likert of the survey, on which it was used the technique of matrix algebra and the optimization to derive weights of regression for the charge of items about the latent factors, which generated a matrix of polychoric correlation of items and allowed evaluate the correlation of each item according to the answers of the 208 respondents.

In this analysis, it was noticed that two of the eighteen items had a low correlation towards the other ones, as it will be demonstrated later on this paper. The noted items were "Introduction of exotic species" and "Street washing". There were made simulations using Cronbach's Alpha calculation without the mentioned items, but it was noticed that the result of reliability was kept unchanged.

On a third phase, it was made the analysis of reliability of the research, through which a matrix of 18 items of polychoric correlation was calculated and submitted to analysis, where the total of the Cronbach's alpha was of 0.92 , which shows a high level of reliability. The summary of the dispersion of the answers of each of the 208 respondents can be seen in the following Table 2.

As a result of the research analysis, it was obtained a Table 3, as follows, on which the variables are put in descending order according to their respective loading

Table 2 Dispersion of the answers for each variable.

\begin{tabular}{|c|c|c|c|c|c|}
\hline \multirow[b]{2}{*}{ Urban sanitary waste dumping } & \multicolumn{4}{|c|}{ Relevance of the factors in the process of the degradation } & \multirow[b]{2}{*}{$88 \%$} \\
\hline & $4 \%$ & & 86 & & \\
\hline Irregular urban waste dumping & $1 \%$ & & 56 & & $93 \%$ \\
\hline Industrial effluents dumping & $1 \%$ & & 76 & & $92 \%$ \\
\hline Illegal sewage connection & $5 \%$ & & $11 \%$ & & $84 \%$ \\
\hline Riparian deforestation & $4 \%$ & & $18 \%$ & & $78 \%$ \\
\hline Urban waste sliding & $3 \%$ & & 1986 & & $78 \%$ \\
\hline Agrotoxic sliding & $9 \%$ & & $198 \%$ & & $72 \%$ \\
\hline River siltation process & $6 \%$ & & $21 \%$ & & $73 \%$ \\
\hline Irregular occupation & $6 \%$ & & $23 \%$ & & $71 \%$ \\
\hline Solid material sliding & $10 \%$ & & $31 \%$ & & $59 \%$ \\
\hline Rain sewage & $5 \%$ & & $2 \approx \pi$ & & $73 \%$ \\
\hline Riverbeds rectification & $9 \%$ & & $28 \%$ & & $63 \%$ \\
\hline Drainage of flooded areas & $19 \%$ & & $21 \%$ & & $60 \%$ \\
\hline Underground manure sliding & $7 \%$ & & $1 \pi \pi$ & & $76 \%$ \\
\hline$\underset{\text { Wata }}{\text { Global climate change }}$ & $16 \%$ & & 298 & & $54 \%$ \\
\hline Waterproofing of soil and surfaces & $15 \%$ & & $28 \%$ & & $57 \%$ \\
\hline Introduction of exotic species & $37 \%$ & & $20 \%$ & & $34 \%$ \\
\hline \multirow[t]{3}{*}{ Street washing } & $41 \%$ & & $15 \%$ & & $24 \%$ \\
\hline & \multicolumn{5}{|c|}{ Percentage } \\
\hline & Variable & Very little relevant & Relevant & Very relevant & Extremely relevant \\
\hline
\end{tabular}


Table 3 Variables and respective loading factors.

\begin{tabular}{lllll}
\hline Item & Scale correlation & Loading Factor & Average & Standard Deviation \\
\hline Urban sanitary wastewater dumping (A) & 0.71619 & 0.76326 & 4.31250 & 0.83025 \\
Irregular dumping of urban waste (B) & 0.70255 & 0.76161 & 4.49038 & 0.68799 \\
Industrial effluent dumping (C) & 0.69496 & 0.74477 & 4.49038 & 0,70875 \\
Illegal sewage connection (D) & 0.70316 & 0.74166 & 4.22115 & 0.89504 \\
Riparian deforestation (E) & 0.69911 & 0.72727 & 4.12500 & 0.87573 \\
Urban waste sliding (F) & 0.65826 & 0.69993 & 4.12019 & 0.84555 \\
Agrotoxics sliding (G) & 0.67246 & 0,69861 & 3,99038 & 1.03555 \\
River siltation process (H) & 0.63852 & 0.66311 & 3.94231 & 0.88822 \\
Solid material sliding (I) & 0.62456 & 0.64662 & 3.70673 & 0.92499 \\
Irregular occupation (J) & 0.61248 & 0.64301 & 3.92788 & 0.90067 \\
Rain sewage (K) & 0.58934 & 0.61670 & 4.01923 & 0.90068 \\
River bed rectification (L) & 0.58603 & 0.60433 & 3.70673 & 0.90386 \\
Drainage of flooded areas (M) & 0.57427 & 0.58773 & 3.57692 & 1.10940 \\
Underground manure drainage (N) & 0.55326 & 0.57944 & 4.00481 & 0.93508 \\
Global climate changes (O) & 0.52532 & 0.54359 & 3.59615 & 1.12520 \\
Waterproofing of soil and surfaces (P) & 0.51933 & 0.53192 & 3.57212 & 1.03774 \\
Introduction of exotic species (Q) & 0.43995 & 0.44956 & 2.97115 & 1.16683 \\
Street washing (R) & 0.42204 & 0.42904 & 2.73077 & 1.09218 \\
\hline
\end{tabular}

factor. From the Evolution of the analysis is obtained the polychoric correlation matrix of the factors as shown in the following Table 4, which will be the main basis for the clusters' analysis and the ordering of correlations between the factors.

Table 4 shows the results of the intersection of two adjacent categories called GPCM (Generalized Partial Credit Model) [20, 24].

In order to achieve the objectives of this study there was used the cluster analysis (ICLUST) seeking the verification of possible variable gatherings. Cooksey and Soutar [25] explain that this analysis is an alternative to the factorial one for the gathering of items because it considers at the same time the alpha and beta coefficients. The alpha coefficient is the most widely used internal consistency measure. However, it must be taken into consideration that in its analysis, only one underlying factor is taken [26].

Besides, the alpha coefficient is defined by the averages of verified covariance, which may lead to acceptable values, even when they do not correspond to reality [27]. Revelle [27] proposes the use of the beta coefficient stressing that it is a more conservative estimation, using the inferior limit of variance, associating it to the general factor. Besides, the author stresses that this coefficient is more appropriate for analysis involving various components or factors linked to the mentioned general factor.

Therefore, as Cooksey and Soutar [25] conclude, the ICLUST is a procedure which makes the gatherings using simultaneously the alpha and beta coefficients in the formation of clusters, being the best option for hierarchical gatherings with good psychometric criteria to evaluate the internal consistency and dimensionality. The result of the analysis can be seen on Fig. 5, as follows.

In this Fig. 5, the variable that start with "V" are related to the factors analyzed, and there it is possible to observe the formation of 17 clusters, many of them formed by sub-clusters. The first one to be observed with the highest correlation is the $\mathrm{C} 1$, which indicates the gathering of the variables V15 ("Irregular dumping of urban waste") and V2 ("Dumping of Industrial effluents”), which are respectively the second and third factors of higher charge.

In the sequence, the $\mathrm{C} 4$ which indicates the gathering of C1 and V1 ("Dumping of urban sanitary effluents”), being this the fourth factor of highest 
Table 4 Psychological Distance of the Factors by the GPCM (Generalized Partial Credit Model).

\begin{tabular}{|c|c|c|c|c|c|c|c|c|c|c|c|c|c|c|c|c|c|c|}
\hline Item & $\mathrm{A}$ & $\mathrm{C}$ & $\mathrm{K}$ & $\mathrm{F}$ & $\mathrm{G}$ & $\mathrm{N}$ & $\mathrm{R}$ & I & $\mathrm{D}$ & $\mathrm{P}$ & $\mathrm{H}$ & $\mathrm{L}$ & $\mathrm{E}$ & $\mathrm{J}$ & B & $\mathrm{M}$ & $\mathrm{O}$ & Q \\
\hline $\begin{array}{l}\text { Urban sanitary waste } \\
\text { dumping }(\mathrm{A})\end{array}$ & 1 & 0.626 & 0.542 & 0.587 & 0.524 & 0.440 & 0.197 & 0.479 & 0.602 & 0.382 & 0.491 & 0.397 & 0.531 & 0.504 & 0.681 & 0.426 & 0.347 & 0.206 \\
\hline $\begin{array}{l}\text { Industrial effluents dumping } \\
\text { (C) }\end{array}$ & 0.626 & 1 & 0.469 & 0.540 & 0.557 & 0.493 & 0.206 & 0.464 & 0.581 & 0.324 & 0.496 & 0.436 & 0.524 & 0.488 & 0.681 & 0.320 & 0.363 & 0.171 \\
\hline Rain sewage $(\mathbf{K})$ & 0.542 & 0.469 & 1 & 0.446 & 0.406 & 0.304 & 0.228 & 0.382 & 0.404 & 0.365 & 0.357 & 0.345 & 0.436 & 0.378 & 0.484 & 0.358 & 0.463 & 0.255 \\
\hline Urban waste sliding(F) & 0.587 & 0.540 & 0.446 & 1 & 0.473 & 0.426 & 0.253 & 0.527 & 0.544 & 0.355 & 0.367 & 0.320 & 0.529 & 0.467 & 0.632 & 0.366 & 0.288 & 0.234 \\
\hline Agrotoxics sliding (G) & 0.524 & 0.557 & 0.406 & 0.473 & 1 & 0.508 & 0.371 & 0.418 & 0.507 & 0.396 & 0.443 & 0.379 & 0.572 & 0.425 & 0.441 & 0.359 & 0.359 & 0.366 \\
\hline $\begin{array}{l}\text { Undergroung manure sliding } \\
(\mathrm{N})\end{array}$ & 0.440 & 0.493 & 0.304 & 0.426 & 0.508 & 1 & 0.235 & 0.308 & 0.408 & 0.353 & 0.334 & 0.363 & 0.411 & 0.330 & 0.447 & 0.329 & 0.257 & 0.290 \\
\hline Street washing (R) & 0.197 & 0.206 & 0.228 & 0.253 & 0.371 & 0.235 & 1 & 0.357 & 0.270 & 0.352 & 0.309 & 0.252 & 0.321 & 0.262 & 0.186 & 0.348 & 0.306 & 0.358 \\
\hline Solid material sliding (I) & 0.479 & 0.464 & 0.382 & 0.527 & 0.418 & 0.308 & 0.357 & 1 & 0.480 & 0.369 & 0.488 & 0.375 & 0.411 & 0.390 & 0.415 & 0.430 & 0.358 & 0.346 \\
\hline Illegal sewage connection (D) & 0.602 & 0.581 & 0.404 & 0.544 & 0.507 & 0.408 & 0.270 & 0.480 & & 0.318 & 0.485 & 0.471 & 0.508 & 0.541 & 0.649 & 0.411 & 0.316 & 0.331 \\
\hline $\begin{array}{l}\text { Waterproofing of soil and } \\
\text { surfaces }(\mathrm{P})\end{array}$ & 0.382 & 0.324 & 0.365 & 0.355 & 0.396 & 0.353 & 0.352 & 0.369 & 0.318 & 1 & 0.363 & 0.359 & 0.354 & 0.369 & 0.276 & 0.399 & 0.255 & 0.281 \\
\hline River siltation process $(\mathbf{H})$ & 0.491 & 0.496 & 0.357 & 0.367 & 0.443 & 0.334 & 0.309 & 0.488 & 0.485 & 0.363 & 1 & 0.480 & 0.495 & 0.465 & 0.462 & 0.332 & 0.444 & 0.333 \\
\hline River beds rectification (L) & 0.397 & 0.436 & .0345 & 0.320 & 0.379 & 0.363 & 0.252 & 0.375 & 0.471 & 0.359 & 0.480 & 1 & 0.433 & 0.348 & 0.394 & 0.453 & 0.385 & 0.399 \\
\hline Riparian deforestation (E) & 0.531 & 0.524 & 0.436 & 0.529 & 0.572 & 0.411 & 0.321 & 0.411 & 0.508 & 0.354 & 0.495 & 40.33 & 1 & 0.497 & 0.586 & 0.415 & 0.396 & 0.368 \\
\hline Irregular occupation (J) & 0.504 & 0.488 & 0.378 & 0.467 & 0.425 & 0.330 & 0.262 & 0.390 & 0.541 & 0.369 & 0.465 & 0.348 & 0.497 & 1 & 0.518 & 0.358 & 0.300 & 0.230 \\
\hline $\begin{array}{l}\text { Irregular urban waste } \\
\text { dumping (B) }\end{array}$ & 0.681 & 0.681 & 0.484 & 0.632 & 0.441 & 0.447 & 0.186 & 0.415 & 0.649 & 0.276 & 0.462 & 0.394 & 0.586 & 0.518 & 1 & 0.393 & 0.397 & 0.178 \\
\hline Drainage of flooded areas $(\mathrm{M})$ & 0.426 & 0.320 & 0.358 & 0.366 & 0.359 & 0.329 & 0.348 & 0.430 & 0.411 & 0.399 & 0.332 & 0.453 & 0.415 & 0.358 & 0.393 & 1 & 0.404 & 0.360 \\
\hline Global climate change $(O)$ & 0.347 & 0.363 & 0.463 & 0.288 & 0.359 & 0.257 & 0.306 & 0.358 & 0.316 & 0.255 & 0.444 & 0.385 & 0.396 & 0.300 & 0.397 & 0.404 & 1 & 0.298 \\
\hline $\begin{array}{l}\text { Introduction of exotic species } \\
\text { (Q) }\end{array}$ & 0.206 & 0.171 & 0.255 & 0.234 & 0.366 & 0.290 & 0.358 & 0.346 & 0.331 & 0.281 & 0.333 & 0.399 & 0.368 & 0.230 & 0.178 & 0.360 & 0.298 & 1 \\
\hline Item & A & $\mathrm{C}$ & $\mathrm{K}$ & F & $\mathrm{G}$ & $\mathrm{N}$ & $\mathrm{R}$ & I & $\mathrm{D}$ & $\mathrm{P}$ & $\mathrm{H}$ & L & $\mathrm{E}$ & $\mathbf{J}$ & B & $\mathrm{M}$ & $\mathrm{O}$ & Q \\
\hline
\end{tabular}

charge. The following is C8 that englobes C7 and V4 ("Urban waste sliding") which represents the sixth factor of highest charge.

The cluster C2 that englobes the variables V13 ("Riparian Deforestation”) and V5 (“Agrotoxics sliding") is the second in correlation between the two variables, which are respectively the sixth and eight factors of highest charge, being C2 and C8 the sub-clusters that form the cluster C9.

The cluster C5 that englobes the variables V11 ("River Siltation process") and V8 ("Solid material sliding") has an expressive correlation between its variables, which are the ninth and tenth factors of highest charge, being C5 and C9 the sub-clusters that form cluster C10. These clusters stand out from the others for having in their components the variables of factors of the highest charge in the analysis done in the research, and their correlations, as previously detached. In general, the cluster analysis pointed out some important gatherings, including evidences of convergent validity of several factors.

These gatherings, as previously described, show that the variables of the tools measure similar $\mathrm{e}$ gathering, in order to make inferences that support that taking of decisions [28].

Thus, as previously described, there were highlighted nine of the main items respectively to their factor of charge, as well as their interrelations, on which we can stress the irregular dumping and the sliding processes. 


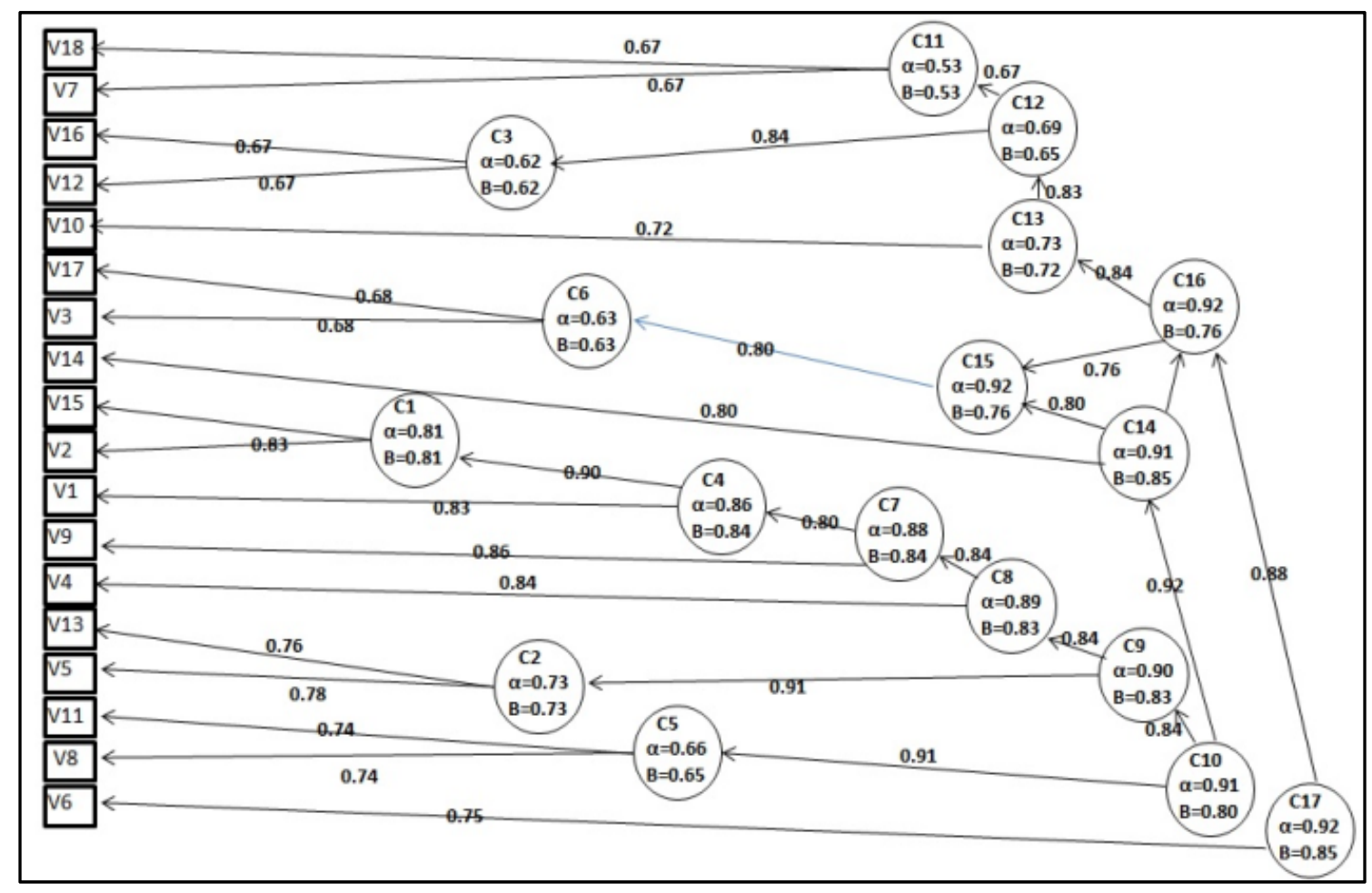

Fig. 5 Hierarchical cluster analysis.

The analysis of these gatherings points out the nine main factors and their correlations which form the most relevant ones, whose mitigation interventions on the impacts over river basins with these characteristics are indispensable.

Invariably, the analysis of the clusters that stand out, always points to irregular dumping, the role of the local communities and of the public powers towards the dealing with water resources, especially in urban environments.

The analysis shows the impacts caused by irregular dumping as well as illegal sewage connections. On a second perspective, we can observe the sliding processes resultant from rains that provoke superficial and water table runoffs, causing the arrival of waste to the water courses, bringing also the contamination and the siltation of riverbeds, which is all increased by riparian deforestation, typical of urban environments. The problem of irregular dumping and sliding of many different types have always been present in studies about water basins which have gone through important processes of urbanization, especially in developing countries, also called semiperipheral, as well as in the peripheral ones.

The irregular dumping of waste is shown in different ways: beyond surface runoff, it infiltrates the soil and percolates towards inferior layers, contaminating them and achieving water tables and watercourses. The analysis of the presented clusters shows the main factors of degradation of urban basins in developing countries, that is, it is an analysis of such factors which represent a higher relevance and correlation that would be perfect objects of intervention of the public powers or private initiative in order to mitigate problems, promoting environmental recovering and improving the quality of life of the present local populations

\section{Conclusions}

The results obtained in this survey based on the Imboaçu river basin show that the critical factors evidenced from the respondents' perspective are present in river basin with different degrees of intensity. 
Based on the respondents' perspectives, it is important to highlight the following critical factors that should be taken into account when assessing a watershed associated with socioeconomic aspects, such as: irregular dumping of urban waste, industrial effluent dumping, urban waste sliding, illegal sewage connection, underground manure drainage and riparian deforestation.

\section{References}

[1] Porto, M. F. A, Porto, R. L. L. 2008. "Gestão de bacias hidrográficas” (River basin management), Estudos avançados, v. 22, n. 63, p. 43-60. (in Portuguese) http://dx.doi.org/10.1590/S0103-40142008000200004.

[2] Yassuda, E. R., 1993. "Gestão de recursos hídricos: fundamentos e aspectos institucionais” (Water resources management: fundamentals and institutional aspects). Revista de Administração Pública, v.27, n.2, p.5-18. (in Portuguese)

[3] Branco, R. R. 2013. "Ontologias para o levantamento e avaliação de aspectos e impactos ambientais oriundos de empreendimentos de engenharia-proposição de um modelo conceitual" (Ontologies for the survey and evaluation of environmental aspects and impacts from engineering endeavors-proposition of a conceptual model). Dissertação, Universidade Federal Fluminense, Rio de Janeiro.

[4] Nunes, A. C., Mainier, F. B., Pinto, F. N., Branco, R. R., \& Nascimento, E. A., 2017. "Concentrações dos metais pesados no sedimento da foz do Rio Imboaçu em constatação aos fatores críticos de degradação de bacias hidrográficas urbanas definidos por dados secundários” (Heavy metal concentrations in the Imboaçu River sediment in light of the critical factors of urban watershed degradation defined by secondary data). Engevista 19 (5) 1303-1319. (in Portuguese)

[5] Afonso, A. E., Rodrigues, F., Armond, N., Brandão, R., \& Morelli, R., 2008. "Análises da dinâmica fluvial do rio Imboaçu (São Gonçalo, RJ): um enfoque a partir da consciência ambiental" (Analysis of the river dynamics of the Imboaçu river (São Gonçalo, RJ): a focus from environmental awareness). In: Simpósio de Recursos Hídricos do Sul-Sudeste, Rio de Janeiro. Rio de Janeiro: Cedipe/UERJ, 2008, 01-18. (in Portuguese)

[6] Amador, E. S., 1997. Baía de Guanabara e Ecossistemas Periféricos: homem e natureza (Guanabara Bay and Peripheral Ecosystems: Man and Nature). Rio de Janeiro: Edição do Autor. (in Portuguese)

[7] Amador, E. S., 2012. Bacia da Baía de Guanabara: características geoambientais, formação e ecossistemas
(Guanabara Bay Basin: geoenvironmental characteristics, formation and ecosystems). Rio de Janeiro: Interciência. (in Portuguese)

[8] Araujo, F. V., Ribeiro, C. R. B., Jayme, M. M. A., \& Nunes-Carvalho, M. C., 2015. "Avaliação da qualidade das águas de seis rios de São Gonçalo e do risco de contaminação à Baía de Guanabara, RJ” (Evaluation of the water quality of six rivers of São Gonçalo and the risk of contamination to Guanabara Bay, RJ). Revista Biociências 21 (1): 1-13. (in Portuguese)

[9] Coelho, V. B. M., 2007. Baía de Guanabara: uma história de agressão ambiental (Guanabara Bay: A History of Environmental Aggression). Rio de Janeiro: Casa da Palavra. (in Portuguese)

[10] Marengo, J. A.; Dias, P. L. S., 2006. "Mudanças climáticas globais e seus impactos nos recursos hídricos” (Global climate change and its impacts on water resources). São Paulo: Escrituras 63-109. (in Portuguese)

[11] Martins, V. A.; Menezes, C. R., Salgado, C. M., 2014 "Bacia hidrográfica urbanizada: o caso do rio Imboaçu São Gonçalo, Região Metropolitana do Rio de Janeiro” (Urbanized watershed: the case of Imboaçu river, São Gonçalo, Rio de Janeiro Metropolitan Region). Revista Geonorte, Edição Especial 4, Manaus, v. 10, n. 1, 166-170. (in Portuguese)

[12] Miranda, A. C., Gomes, H. P., Silva, M. O. 2006. Recursos Hídricos: a gestão das águas, a preservação da vida (Water Resources: water management, preservation of life). São Paulo: All Print. (in Portuguese)

[13] Monteiro, F. F., Cordeiro, R. C., Santelli, R. E., Machado, W., Evangelista, H., Villar, L. S., \& Bidone, E. D., 2012. "Sedimentary Geochemical Record of Historical Anthropogenic Activities Affecting Guanabara Bay (Brazil) Environmental Quality”. Environmental Earth Sciences, $\quad 65 \quad$ (6): $1661-1669$. https://doi.org/10.1007/s12665-011-1143-4.

[14] Santos, M. A., Rahy, I. S., Dominguez, T. M., Viana, J. N. L., 2014, Governança metropolitana na região metropolitana do Rio de Janeiro: Análise da FPIC Saneamento socioambiental (Metropolitan Governance in the Rio de Janeiro Metropolitan Region: FPIC Analysis Social and Environmental Sanitation). Brasília: Ipea. (in Portuguese)

[15] Selles, I. M. A., 2005. Revitalização de bacias hidrográficas e sua influência na mitigação de inundações e na gestão sustentável de recursos hídricos (River basin revitalization and its influence on flood mitigation and sustainable management of water resources). Dissertação, Universidade do Estado do Rio de Janeiro, Rio de Janeiro. (in Portuguese)

[16] Silva, G. A. \& Kulay, L. A., 2006. Água na Indústria (Water in Industry). São Paulo: Escrituras, 367-398. (in 
Portuguese)

[17] Telles, D. D \& Domingues, A. F., 2006. Água na agricultura e pecuária (Water in agriculture and livestock). São Paulo: Escrituras, 325-365. (in Portuguese)

[18] Tucci, C. E. M., 2006. Água no meio urbano (Urban water). São Paulo: Escrituras, 399-432. (in Portuguese)

[19] Tundisi, J. G., Tundisi, T. M., Abe, D. S., Rocha, O., Starling, F., 2006. Limnologia de águas interiores: impactos, conservação e recuperação de ecossistemas aquáticos (Inland water limnology: impacts, conservation and restoration of aquatic ecosystems). São Paulo: Escrituras, 203-240. (in Portuguese)

[20] Wakita, T., Ueshima, N., Noguchi, H. , 2012. "Psychological Distance Between Categories in the Likert Scale Comparing Different Numbers of Options”. Educational and Psychological Measurement 72 (4): 533-546. https://doi.org/10.1177/0013164411431162.

[21] Pituch, K. A. and Stevens, J. P. 2015. Applied Multivariate Statistics for the Social Sciences (6 ed.). New York: Routledge.

[22] Nunnally, J. C. and Bernstein, I. H., 1994. Psychometric Theory. McGraw-Hill.

[23] Kass, R. A., and Tinsley, H. E. A., 1979. "Factor
Analysis”. Journal of Leisure Research v. 11, 120-138.

[24] Muraki, E. A. , 1992. "Generalized Partial Credit Model: Application of an EM Algorithm”. Applied Psychological Measurement 16: 159-176. https://doi.org/10.1002/j.2333-8504.1992.tb01436.x

[25] Cooksey, R. W., Soutar, G. N., 2006. "Coefficient Beta and Hierarchical Item Clustering.” Organizational Research Methods 9 (1): 78-98. https://doi.org/10.1177/1094428105283939.

[26] Cronbach, L. J., 1951. "Coefficient Alpha and the Internal Structure of Tests.” Psychometrika 16 (3) 297-334.

[27] Revelle, W. 1979. "Hierarchical Cluster Analysis and the Internal Structure of Tests.” Multivariate Behavioral Research 14: 57-74. https://doi.org/10.1207/s15327906mbr1401_4.

[28] Schmitt, M., Hofmann, W., Gschwendner, T., Gerstenberg, F. X., Zinkernagel, A., Van de Vijver, A. J. et al. 2015. A Model of Moderated Convergence between Direct, Indirect, and Behavioral Measures of Personality Traits. Behavior based Assessment: Going beyond Self-report in the Personality, Affective, Motivation and Social Domains. Göttingen, Germany: Hogrefe. 